\title{
ANALISIS PEMECAHAN MASALAH DALAM MATERI OPERASI HITUNG DITINJAU DARI PERPSEKTIF STRATEGI HEURISTIK PADA SISWA KELAS IV SEKOLAH DASAR
}

\author{
Ayu Fitri \\ PGSD FKIP UBP Karawang \\ ayufitri@ubpkarawang.ac.id
}

\begin{abstract}
ABSTRAK
Penelitian ini dilatarbelakangi dari jawaban siswa yang beragam ketika menyelesaikan masalah matematika. Untuk mengetahui beragam strategi yang digunakan siswa dalam menyelesaikan masalah, maka dilakukan analisis ditinjau dari perspektif heuristik. Metode penelitian yang digunakan adalah penelitian kualitatif deskriptip. Strategi yang muncul dalam memecahkan masalah pada operasi hitung siswa kelas IV yaitu beraksi, memilih notasi yang efektif, menebak dan menguji, menulis kalimat terbuka, mengidentifikasi informasi yang diinginkan, mengubah sudut pandang, membuat gambar. Kesulitan siswa dalam memecahkan masalah ialah membaca masalah, pengetahuan strategi, kesalahan perhitungan. Sedangakan faktor penyebab kesulitan ialah pengetahuan algoritma, bahasa, konseptual dan strategi.
\end{abstract}

Kata kunci : Pemecahan Masalah, Strategi Heuristik

\begin{abstract}
This research is based on the results various student answers when solving math problems. To know the various strategies used in problem solving, then analyzed from a heuristic perspective. The research method used is qualitative descriptive research. Strategies that arise in solving problems in class IV student counting operations are in action, choosing effective notation, guessing and trying, writing open sentences, desired information, changing point of view, drawing. Difficulty in solving problems. While the factors causing knowledge, language, conceptual and strategy disturbances.
\end{abstract}

Keyword : Problem solving, Heuristic strategi

93. Buana Ilmu 


\section{PENDAHULUAN}

Dalam kurikulum tingkat satuan pendidikan (BSNP, 2006) secara eksplisit dicantumkan pemecahan masalah sebagai salah satu tujuan pembelajaran matematika di sekolah dasar yaitu: (1) memahami konsep matematika, menjelaskan keterkaitan antarkonsep dan mengaplikasikan konsep atau algoritma, secara luwes, akurat, efisien, dan tepat, dalam pemecahan masalah; (2) menggunakan penalaran pada pola dan sifat, melakukan manipulasi matematika dalam membuat generalisasi, menyusun bukti, atau menjelaskan gagasan dan pernyataan matematika; (3) memecahkan masalah yang meliputi kemampuan memahami masalah, merancang model matematika, menyelesaikan model dan menafsirkan solusi yang diperoleh; (4) mengomunikasikan gagasan dengan simbol, tabel, diagram, atau media lain untuk memperjelas keadaan atau masalah; (5) memiliki sikap menghargai kegunaan matematika dalam kehidupan, yaitu memiliki rasa ingin tahu, perhatian, dan minat dalam mempelajari matematika, serta sikap ulet dan percaya diri dalam pemecahan masalah.

Berdasarkan tujuan pembelajaran matematika sebagaimana diungkapkan di atas pemecahan matematika merupakan bagian yang sangat penting dalam kurikulum matematika sekolah dasar, karena untuk mencapai salah satu tujuan tersebut, siswa diharapkan dapat menguasai konsep dasar matematika secara benar serta dapat menyelesaikan pemecahan masalah sehingga dapat menerapkannya dalam kehidupan sehari-hari maupun dalam mempelajari matematika di jenjang sekolah selanjutnya. Melalui kegiatan pemecahan masalah, aspek-aspek kemampuan matematika yang penting seperti penerapan aturan pada masalah tidak rutin, penemuan pola, penggeneralisasian, komunikasi matematika dan lain-lain dapat dikembangkan secara lebih baik (Suherman, 2001, hal. 93).

Pentingnya pemecahan masalah juga ditegaskan dalam NCTM (2000) bahwa pemecahan masalah merupakan bagian integral dalam pembelajaran matematika dan menjadi keterampilan matematis yang perlu dikuasai siswa. Kemampuan pemecahan masalah penting dimiliki siswa untuk mencapai hasil belajar yang optimal. Keterampilan-keterampilan tersebut termasuk pada berpikir matematika tingkat tinggi (high order mathematical thinking) yang harus 
dikembangkan dalam proses pembelajaran matematika. The National Council of Supervisor of Mathematics (NCSM) menyatakan bahwa "Belajar menyelesaikan masalah adalah utama untuk mempelajari matematika" (Posamentier \& Krulik, 2009). Sejalan dengan pendapat Wahyudin (2003) yang menyatakan bahwa pemecahan masalah bukan sekedar keterampilan untuk diajarkan dan digunakan dalam matematika tetapi juga merupakan keterampilan yang akan dibawa pada masalah-masalah keseharian atau situasi-situasi pembuatan keputusan, dengan demikian kemampuan pemecahan masalah membantu seseorang secara baik dalam hidupnya. Dengan pembelajaran pemecahan masalah siswa diberikan kesempatan untuk menghadapi berbagai aspek kehidupannya.

Mengingat pentingnya pemecahan masalah diatas, namun dari hasil studi awal penelitian terungkap ketika diberikan soal pemecahan masalah kepada kelas IV SD pada materi operasi hitung bilangan, pecahan, FPB dan KPK. Menunjukan bahwa siswa merasa kesulitan dalam memahami masalah. Hal ini terbukti pada soal "Bibi akan membuat sebuah pempek palembang. Ia membutuhkan $\frac{1}{2} \mathrm{~kg}$ terigu, dan $\frac{1}{2} \mathrm{~kg}$ sagu. Berapa kg berat belanjaan Bibi?”. Hasil jawaban siswa menyelesaikan dengan operasi hitung perkalian, padahal seharusnya siswa menyelesaikan dengan menggunakan operasi hitung penjumlahan. Kesulitan yang dialami siswa dalam menyelesaikan masalah ini ialah siswa belum dapat memahami masalah, memilih operasi hitung yang digunakan, kurangnya kemampuan berhitung siswa dan kurangnya pengalaman siswa. Hal ini sejalan dengan pendapat Bailey, (Bruun, 2013) yang mengemukakan bahwa kesulitan dalam menyelesaiakan pemecahan masalah yaitu karena terbatasnya pengalaman siswa dalam masalah tersebut.

Dari hasil jawaban siswa terdapat banyak cara yang digunakan siswa untuk memecahkan masalah. Kemudian peneliti melakukan wawancara kepada guru kelasnya, ia terkejut melihat jawaban siswanya yang sangat beragam. Siswa biasanya menjawab soal pemecahan masalah dengan langsung menjawab tanpa menggunakan cara. Biasanya siswa menyelesaikan pemecahan masalah pada buku tulis yang tidak terpakainya, sehingga siswa menuliskan hasil jawabannya tanpa menggunakan cara pada kertas jawabannya. Dengan kata lain siswa mempunyai 
beragam strategi dalam menyelesaikan masalahnya, namun masih terbatas kesempatannya untuk menunjukkan kemampuannya tersebut.

Sementara itu pemecahan masalah matematika tidak menuntut siswa dalam menyelesaikan dengan satu langkah pengerjaan saja, namun banyak cara yang dapat digunakan dalam menyelesaikan masalah. Strategi pemecahan masalah menurut Reys (Aisyah, 2008) yaitu beraksi (Act it Out), membuat gambar atau diagram, mencari pola, membuat tabel, menghitung semua kemungkinan secara sistematis, menebak dan menguji, bekerja mundur, mengidentifikasi informasi yang diinginkan, menulis kalimat terbuka, menyelesaikan masalah yang lebih sederhana atau serupa, mengubah pandangan. Hasil observasi yang dilakukan kepada siswa kelas IV siswa sudah ada yang menggunakan strategi heuristik dalam memecahkan masalah yaitu mengubah sudut pandang, ia tidak bisa perkalian, maka ia menjumlahkan sampai ketemu dengan hasilnya.

Strategi heuristik dalam pembelajaran matematika merupakan langkahlangkah atau tahapan-tahapan berpikir yang membantu seseorang dalam menyelesaikan soal matematika khususnya soal cerita. Heuristik itu sendiri berasal dari kata yunani yaitu heuriskein artinya "to discover" yang berarti menemukan. Menurut Martf \& Reincnelt (2011) bahwa metode heuristik ialah metode yang fleksibel dibandingkan metode yang lain, karena metode ini merupakan prosedur menyeluruh untuk menemukan solusi dalam masalah. Hal ini sejalan dengan pendapat yang dikemukakan oleh Chu, Yun; Zheng Li; Yong Su (2010) yang bahwa "That the problem solver may be able to decide the next step without checking alternative step". Untuk memecahkan masalah banyak cara yang dapat digunakan, namun dengan menggunakan strategi heuristik merupakan salah satu cara yang dapat digunakan untuk memecahkan masalah secara optimal. Jadi strategi heuristik adalah sebuah strategi belajar mengajar yang menyiasati langkah-langkah dalam menyelesaikan sesuatu tanpa ada keharusan untuk dilakukan secara berurutan dan mengarah kepada pengaktifan siswa.

Adapun langkah-langkah pemecahan masalah menurut Polya (1945) dirincikan menjadi empat langkah penting yaitu:

1. Memahami masalah 
Langkah ini dimana membantu siswa menetapkan apa yang diketahui dan apa yang ditanyakan dalam soal tersebut. Guru juga dapat memberikan pertanyan kepada siswa dengan menggunakan pertanyaan: a) apa yang diketahui dari soal? Apa yang ditanyakan soal? Apa saja informasi yang diperlukan?, bagaimana penyelesaiannya?. Dengan pertanyaan tersebut membantu siswa dalam memahami soal.

\section{Merencanakan masalah}

Pada langkah ini siswa diarahkan untuk dapat mengidentifikasi strategi-strategi pemecahan masalah yang sesuai dengan permasalahan tersebut, setiap orang mempunyai strategi berbeda untuk menyelesaikan masalah.

3. Menyelesaikan masalah

Langkah ini siswa menyelesaikan masalah sesuai dengan strategi yang telah dipilih. Penelitian ini memfokuskan kepada langkah ketiga ini dimana akan diketahui gambaran strategi yang digunakan oleh siswa dalam menyelesaikan masalah.

4. Memeriksa kembali

Setelah mengerjakan soal siswa mengecheck kembali hasil jawabannya, bisa dengan meneliti kembali prosuder penyelesaiannya sehingga yakin dengan jawaban hasil pengerjaannya. Siswa yang tidak melakukan pengecheckan kembali terkadang rentang melakukan kesalahan dalam pengerjaannya seperti kesalahan pemahaman konsep, kesalahan penggunaan operasi hitung, algoritma yang tidak sempurna, dan kesalahan karena mengerjakan serampangan/ceroboh (Abdurrahman, 1999, hal. 28).

Dalam pembelajaran pemecahan masalah tidak semua siswa dapat menyelesaikannya, ada sebagaian siswa yang merasa kesulitan. Menurut Soegiono (1984, hal 214) menyatakan bahwa kesulitan-kesulitan siswa dalam menyelesaikan soal-soal matematika adalah sebagai berikut:

1. Ketidakmampuan siswa dalam penguasaan konsep secara benar, indikator dari kesulitan ini meliputi kesalahan dalam menentukan teorema atau rumus-rumus untuk menjawab masalah, penggunaan teorema atau rumus yang tidak sesuai dengan kondisi prasyarat berlakunya rumus tersebut. 
2. Ketidakmampuan menggunakan data, kesulitan ini antara lain siswa tidak menggunakan data yang seharusnya dipakai, kesalahan memasukkan data ke dalam variabel tertentu, menambah data yang tidak diperlukan dalam menjawab suatu masalah.

3. Ketidakmampuan mengartikan bahasa matematika, indikator kesulitan ini adalah kesalahan menginterpretasikan simbol-simbol, grafik, tabel dalam matematika.

4. Ketidakcermatan dalam melakukan operasi hitung, indikator dari penyebab kesulitan ini adalah siswa melakukan kesalahan dalam operasi hitung dan tidak melakukan operasi hitung yang seharusnya dilakukan dalam operasi tersebut.

5. Ketidakmampuan dalam menarik kesimpulan, indikator dari kesulitan ini antara lain kesalahan dalam menarik kesimpulan ataupun siswa tidak mampu dalam menarik kesimpulan.

Adapun faktor-faktor yang menyebabkan siswa mengalami kesulitan melakukan aktivitas belajar yang dikemukakan oleh Sodjono (Askury, 1999) meliputi:

1. Kesulitan menggunakan konsep, dalam hal ini diasumsikan bahwa siswa telah memperoleh pembelajaran mengenai konsep, tetapi belum menguasai dengan baik karena mungkin lupa sebagian atau seluruhnya. Mungkin juga penguasaan siswa atas suatu konsep masih kurang jelas atau kurang cermat sehingga ia kesulitan dalam menggunakannya.

2. Kurangnya keterampilan operasi aritmetika, kesulitan yang disebabkan oleh kekurangmampuan dalam mengoperasikan secara tepat kuantitas-kuantitas yang terdapat dalam soal.

3. Kesulitan menyelesaikan soal cerita, disebabkan kesulitan siswa memahami cerita itu, menetapkan besaran-besaran yang ada serta hubungannya sehingga diperoleh model matematika dan menyelesaikan model matematika tersebut secara matematika. Kadangkala siswa juga kesulitan dalam menentukan apakah bilangan yang merupakan selesaian model matematika itu merupakan jawab dari masalah semula.

98. Buana Ilmu 


\section{METODE PENELITIAN}

Metode penelitian merupakan usaha untuk mengumpulkan data secara objektif, artinya data yang dikumpulkan merupakan data yang benar-benar dapat dipercaya. Penelitian ini menggunakan penelitian kualitatif deskriptip dengan mengumpulkan data dan mencatat fenomena yang terjadi baik secara langsung dan tidak langsung, kemudian data digambarkan berupa kata-kata atau uraian deskriptif tanpa mengabaikan data berbentuk kata-kata. Penelitian ini bertujuan untuk menganalisis pemecahan masalah ditinjau dari strategi perspektif heuristik.

Partisipan penelitian ini terdiri dari dua sekolah dengan kategori sekolah terbaik tingkat kabupaten karawang diwakili, SD Negeri Nagasari VI sebanyak 40 siswa, sedangkan dan tingkat kecamatan, diwakili SD Negeri Rengasdengklok Selatan II berjumlah 24 orang siswa. Adapun teknik pengumpulan yang dilakukan dalam penelitian ini adalah pemberian tes pemecahan masalah, observasi, wawancara siswa dan lembar wawancara guru. Sedangkan instrumen yang digunakan dalam penelitian ini adalah lembar hasil tes siswa, lembar observasi, lembar wawancara siswa dan lembar wawancara guru. Proses analisis data dalam penelitian ini sebelum masuk lapangan sehingga mendapatkan data awal untuk menemukan masalah dan fokus masalah. namun fokus penelitian ini bersifat sementara akan berkembang setelah peneliti masuk ke lapangan. Analisis penelitian ini menggunakan model Miles dan Huberman yaitu mengumpulkan data, mereduksi data, mendisplay data, menyimpulkan data.

Data diperoleh dari hasil observasi di lapangan, dokumentasi, wawancara dan hasil jawaban siswa. Analisis data dilakukan selama dan setelah pengumpulan data, agar data yang diperoleh tersusun secara sistematis dan lebih mudah menafsirkan sesuai dengan rumusan masalah. Langkah-langkah analisis dan penafsiran data dilakukan dengan tahapan sebagai berikut: Mengumpulkan dan memformulasikan semua data yang diperoleh dari lapangan, menganalisis lebih dalam lagi tentang jenis kesulitan siswa pada setiap item soal untuk menentukan faktor yang mempengaruhi kesulitan siswa. Kegiatan yang dilakukan pada tahap ini adalah dengan menentukan faktor yang mempengaruhi kesulitan siswa berdasarkan jenis kesulitan yang ditemukan dari hasil tes, kemudian penarikan kesimpulan 
berdasarkan analisis terhadap data yang telah dikumpulkan, baik melalui tes maupun dokumentasi.

Prosedur penelitian ini dimulai dengan mengadakan observasi ke sekolah untuk melihat kesulitan siswa dalam menyelesaikan pemecahan masalah. Kegiatan berikutnya adalah mengkaji teori tentang strategi heuristik dalam pemecahan masalah sebagai bagian untuk memperoleh jenis masalah dan pola strategi heuristik dalam pemecahan masalah. Selain itu disusun juga instrumen pendukung yakni soal pemecahan masalah. Instrumen tes pemecahan masalah kemudian dikonsultasikan dengan pembimbing dan divalidasi oleh beberapa ahli serta diujicobakan untuk mendapatkan instrumen mudah dipahami serta dapat memunculkan penggunaan strategi heuristik dalam menyelesaikan permasalahan. Ketika diujicobakan kepada siswa, peneliti mengobservasi kegiatan siswa dalam menyelesaikan masalah. Kegiatan akhir adalah analisis data hasil pekerjaan siswa dan wawancara kepada siswa dan guru berkaitan dengan penggunaan strategi dan kesulitan siswa dalam menggunakan strategi tersebut.

\section{HASIL PENELITIAN}

Bahasan hasil penelitian di bawah ini merupakan hasil yang diperoleh peneliti melalui proses observasi lembar kerja siswa, wawancara, dan studi dokumentasi selama melaksanakan penelitian. Observasi lembar kerja siswa ini peneliti laksanakan di kelas IV untuk mengetahui pola strategi yang digunakan siswa dalam memecahkan masalah matematika. Untuk memperkuat pemilihan strategi heuristik siswa dilakukan dengan wawancara. Wawancara dilakukan kepada siswa dan guru. Wawancara guru dilakukan kepada delapan responden meliputi guru kelas guru IV, III, II, dan I SDN Nagasari VI serta guru IV, III, II, dan I SDN Rengasdengklok Selatan II. Peneliti juga melakukan telaah terhadap dokumen RPP dan buku pegangan guru.

Semua data hasil penelitian ini diuraikan berdasarkan bagian masalah dengan tujuan penelitian yang ditentukan yaitu: pola strategi heuristik dalam menyelesaikan soal pemecahan masalah berkaitan dengan operasi hitung, kesulitan 
siswa dalam menjalankan stategi heuristik dan faktor penyebab kesulitan siswa dalam menjalankan stategi heuristik.

1. Pola strategi heuristik menurut Reys yaitu beraksi (Act it Out), membuat gambar atau diagram, mencari pola, membuat tabel, menghitung semua kemungkinan secara sistematis, menembak dan menguji, bekerja mundur, mengidentifikasi informasi yang diinginkan, menulis kalimat terbuka, menyelesaikan masalah yang lebih sederhana atau serupa, mengubah pandangan. Namun dari 12 strategi heuristik tersebut, strategi yang muncul dalam memecahkan masalah pada operasi hitung siswa kelas IV yaitu beraksi, memilih notasi yang efektif, menebak dan menguji, menulis kalimat terbuka, mengidentifikasi informasi yang diinginkan, mengubah sudut pandang, membuat gambar. Adapun strategi yang muncul pada setiap masalah, yaitu:

a. Strategi heuristik yang muncul pada masalah I berupa masalah tertutup mengenai operasi hitung pembagian dan perkalian adalah beraksi, membuat gambar, mengidentifikasi informasi yang diketahui, dan memilih notasi yang efektif.

b. Strategi heuristik yang muncul pada masalah II berupa masalah tertutup mengenai operasi hitung penjumlahan dan pembagian yaitu beraksi mengidentifikasi informasi yang diketahui, dan memilih notasi yang efektif. membuat gambar, menebak dan menguji.

c. Strategi heuristik yang muncul pada masalah III berupa masalah tertutup mengenai operasi hitung penjumlahan dan pengurangan yaitu beraksi, membuat gambar, mengidentifikasi informasi yang diinginkan dan memilih notasi yang efektif.

d. Strategi heuristik yang muncul pada masalah IV berupa masalah terbuka mengenai operasi hitung campuran penjumlahan, perkalian dan pembagian yaitu beraksi, menulis kalimat terbuka dan memilih notasi yang efektif.

e. Strategi heuristik yang muncul pada masalah $\mathrm{V}$ berupa masalah tertutup mengenai operasi hitung penjumlahan dan pengurangan yaitu beraksi, membuat gambar, menuliskan kalimat terbuka dan memilih notasi yang efektif. 
f. Strategi heuristik yang muncul pada masalah VI berupa masalah tertutup mengenai operasi hitung campuran penjumlahan, perkalian dan pembagian yaitu beraksi, menebak dan menguji, menuliskan kalimat terbuka dan memilih notasi yang efektif.

2. Kesulitan siswa dalam menyelesaikan masalah

a. Ketidakmampuan siswa dalam membaca masalah, meliputi siswa masih kesulitan dalam membedakan dijumlah, dikurang, dikali atau dibagi dalam soal cerita.

b. Kurangnya pengetahuan siswa tentang strategi dalam menyelesaikan masalah, siswa terbiasa menggunakan strategi yang berasal pada buku sumbernya, sehingga ketika masalah tersebut memerlukan strategi lain, siswa merasa kesulitan.

c. Kesalahan perhitungan siswa dalam menyelesaikan masalah. Siswa tersebut menyelesaikan masalah tanpa memeriksa kembali hasil jawabannya kemungkinan akan terjadi kesalahan dalam perhitungannya, serta tergesagesa dalam menjawab masalah.

3. Faktor mempengaruhi terhadap kesulitan siswa dalam memecahkan masalah

a. Pengetahuan algoritma, hal ini disebabkan jika siswa yang kemampuan dasar berhitungnya lemah maka akan kesulitan dalam memecahkan masalah

b. Pengetahuan bahasa, jika bahasa yang kurang akrab dengan siswa maka dapat menjadi penghambat dalam pemahaman masalah kata

c. Pengetahuan konseptual, dimana siswa harus memutuskan operasi perhitungan manakah yang akan digunakan dalam memecahkan masalah

d. Pengetahuan strategi, siswa yang merasa kesulitan dalam menyelesaikan masalah diakibatkan kurangnya pengetahuan strategi pemecahan masalah. 


\section{KESIMPULAN}

Pola strategi heuristik menurut Reys yaitu beraksi (Act it Out), membuat gambar atau diagram, mencari pola, membuat tabel, menghitung semua kemungkinan secara sistematis, menembak dan menguji, bekerja mundur, mengidentifikasi informasi yang diinginkan, menulis kalimat terbuka, menyelesaikan masalah yang lebih sederhana atau serupa, mengubah pandangan. Namun dari 12 strategi heuristik tersebut, strategi yang muncul dalam memecahkan masalah pada operasi hitung siswa kelas IV yaitu beraksi, memilih notasi yang efektif, menebak dan menguji, menulis kalimat terbuka, mengidentifikasi informasi yang diinginkan, mengubah sudut pandang, membuat gambar.

Kesulitan siswa dalam menyelesaikan masalah meliputi ketidakmampuan siswa dalam membaca masalah, kurangnya pengetahuan siswa tentang strategi dalam menyelesaikan masalah, dan kesalahan perhitungan siswa dalam menyelesaikan masalah. Adapun faktor mempengaruhi tterhadap kesulitan siswa dalam memecahkan masalah dipengaruhi oleh pengetahuan algoritma, pengetahuan bahasa, pengetahuan konseptual dan pengetahuan strategi.

\section{REFERENSI}

Abdurrahman, M. (1999). Pendidikan bagi Anak Berkesulitan Belajar. Jakarta: Depdikbud dan PT. Rineka Cipta.

Aisyah, N. (2008). Pengembangan Pembelajaran Matematika Sekolah Dasar. Jakarta: Depdiknas.

Askury. (1999). Kesulitan Belajar Matematika Permasalahan dan Alternatif Pemecahannya. Jurnal Matematika dan Pembelajaran, Th. V No. 1 Februari 1999, 137.

Bruun, F. (2013). Elementary Teachers Perspectives of Methematics Problem Solving Strategies. The Mathematics Educator, 23, 45-59.

BSNP. (2006). Standar Isi Untuk Satuan Pendidikan Dasar dan Menengah, Standar Kompetensi dan Kompetensi Dasar SD/MI. Jakarta: Depdiknas. 
Chu, Yun; Zheng Li; Yong Su. (2010). Heuristic in Problem Solving: The Role of Direction in Controlling. The Journal of Problem Solving, 3, 27-51.

English, L. D., \& Lesh, R. a. (2008). Future Directions and Perspectives For Problem Solving Research and Curriculum Development. Monterre, Mexico: Unpublished.

Krulik, \& Rays. (1980). Problem Solving in School Mathematics. Virginia: NCTM.

Martf, R., \& Reincnelt, G. (2011). The Linear Ordering Problem, Exact, and Heuristic Methods in Combinatoral Optimization. Spinger, 17-40.

NCTM. (2000). Principles and Standars for School Mathematics. USA: The National Council of Teacher Mateics ins.

Posamentier, A., \& Krulik, A. (2009). Problem Solving in Mathematics Grade 3-6. United States of America: Corwin.

Schoenfeld. (1985). Mathematical problem solving. Orlando,Fl: Academic Press, Inc.

Schoenfeld. (1992). Learning to think mathematically: Problem Solving metacognition, and sense making in mathematics. In D. A Grouws Handbook of research on mathematics teaching and learning. New York: Macmillan.

Shadiq, F. (2004). Pemecahan Masalah Penalaran dan Komunikasi dalam Pembelajaran Matematika. Yogyakarta: Depdikdas Dirjen Dikdasmen PPPGMatematika.

Sikhafus, E. (2004). Heuristik for Solving TRehnical Problem. Grosse: Ntelleck LLC.

Sugiyono. (2013). Metode Penelitian Pendidikan . Bandung: Tarsito

Suherman, E. (2001). Strategi Pembelajaran Matematika Kontemporer. Bandung: JICA-UPI.

Tambunan, H. (2014). Strategi Heuristik dalam Pemecahan Masalah Matematika Sekolah. Jurnal Saintech Vol. 6 No. 4 Desember 2014. 
Widdiharto, \& Rachmadi. (2008). Diagnosis Kesulitan Belajar Matematika SMP dan Alternatif Proses remedinya. Yogyakarta: Depdiknas Yogyakarta. 